RAJKO HORVAT, M.Sc.

Email: rajko.horvat@fpz.hr

University of Zagreb,

Faculty of Transport and Traffic Sciences

Vukelićeva 4, 10000 Zagreb, Republic of Croatia

BERISLAV BARIŠIĆ-JAMAN, B.Eng.

Email: bbarisic@mup.hr

GORDAN MRŠIć, B.Eng.

Email: gmrsic@mup.hr

IGOR ŠPOLJARIĆ

Email: ispoljaric@mup.hr

ANDRO VRDOLJAK, B.Eng.

Email: avrdoljak@mup.hr

Forensic Science Centre "Ivan Vučetić",

General Police Directorate,

Ministry of the Interior

Zagreb, Croatia.

IVAN PEHAR

ivan.pehar@dekra.hr

Dekra expert d.o.o.

Zagrebačka 118, 10000 Zagreb, Sesvete
Safety and Security in Traffic Preliminary Communication Accepted: Feb. 1, 2010 Approved: July 5, 2010

\title{
METHOD OF LIGHT BULBS ANALYSIS ON VEHICLES DAMAGED IN TRAFFIC ACCIDENTS
}

\section{ABSTRACT:}

One of the measures to increase road traffic safety in Croatia is the introduction of obligatory use of daily lights on vehicles in road traffic during driving, regardless of the visibility and the time of day. The paper describes the new original technical and technological procedure of analysing automotive light bulbs in order to find the traces of glass particles of the broken glass balloon in the marginal cases of action of small inertia forces generated as result of a traffic accident. Investigations of light bulbs in traffic accidents had been rarely done before; therefore the subject of this scientific research is the analysis of the light bulb filament used in automobiles to light the road ahead and to give light signals, i.e. all the light signalling devices on the automobile using the new technical and technological procedure by means of SEM/EDX method. The scientific research has improved the investigation procedure in analysing the light bulbs on automobiles in determining whether at the moment of the traffic accident the regulatory lights were switched on. In determining the responsibility of participants for causing the traffic accident, such a fact may sometimes be of crucial significance.

\section{KEY WORDS}

traffic accident, light bulb, technical and technological procedure, lights in traffic, microscope, molten glass particles

\section{INTRODUCTION}

The World Health Organisation (WHO) has confirmed that injuries and fatalities in traffic accidents belong to the category of "epidemics of the modern age" like "Spanish Flu", when every day on the roads worldwide there are about 140,000 people injured, more than 3,000 die and about 15,000 become disabled for their entire lives. It was, namely, found already in the 1990s that among the causes of human mortality, death as consequence of traffic accidents occupied the ninth place. The alarming characteristic of this condition is confirmed also by the data according to which, if such trend continued until 2020, the consequences of traffic accidents will become third among the leading causes of health disturbance, disabilities and deaths. In order to stop this trend in the world various measures are being undertaken, ranging from legal, administrative, technical to organisational ones. The introduction of obligatory use of daily lights [1] on automobiles in road traffic during driving, regardless of visibility and time of day for better vehicle conspicuousness is one of the measures accepted also by Croatia.

However, determining whether at the moment of the traffic accident the regulated lights were switched on, i.e. whether the light bulb filament on the vehicle 
was in the glowing or cold state, may sometimes be of crucial importance in the procedure of determining the responsibility of the participants in causing the accident. The mentioned fact, that will provide answer to this question from the technical aspect, can be determined only by investigation. The examples of single cases from practice, published in scientific papers, prove how important it is to integrate all the circumstances related to the traffic accident and the interpretation of the results $[2,3]$.

Since up to now the light bulb investigations in traffic accidents were very seldom performed, the subject of this scientific research is the light bulb filament which is used in automobiles to light the road ahead and to give light signals, i.e. of all the light signalling devices on an automobile using new technical and technological methods by means of SEM/EDX method. The problems of this kind of investigation, namely, are not limited to simply determining whether the respective light bulb had been switched on or off, but rather it is often necessary to answer a number of other questions such as: which lights were on (high-or low beams), whether or not the turn indicators were on, whether the driver was braking at the moment of the traffic accident or not, and whether a certain light bulb had been functioning properly at the moment of accident $[4,5]$. All this is subject of this scientific research with the aim of increasing road traffic safety.

\section{TYPES AND WORKING PRINCIPLES OF ANALYSED LIGHT BULBS}

Although technically and technologically the light bulbs for vehicles in road traffic are constantly developing and there is an increasing tendency of fitting light bulbs without tungsten filaments but rather filled with colourless gas obtained by fraction distillation of liquid air xenon, the filament light bulbs are still mostly used. Basically, all light bulbs operate on the same principle regardless of the differences in the design and form of the glass balloon, appearance and design of filaments or supports of filaments, or of the nominal voltage and power. In a filament light bulb there comes to transformation of electrical energy into light energy which results from the Ohm resistance $(R)$ which is generated in the tungsten filament with the passage of electricity of power $I$ and voltage $U$. These three values are interconnected by the Ohm's law and presented by the following equation:

$R=\frac{U}{l}[\Omega]$

By passing of electrical energy through the filament (conductor), due to Ohm resistance the conductor becomes hot [6]. Since metals have the property that their resistance increases with the increase in temperature, the Ohm resistance of a glowing filament is about 13 times greater than the resistance provid- ed by a cold filament with the passage of electricity. Thus, when a filament of calculated cross-section and length due to the passage of electricity reaches the glowing state, it starts to emit intensive light. The filament is made of tungsten wire which was cold drawn. The working temperature of the filament depends on the construction characteristics of the bulb. In classic bulbs it ranges from $1,900-2,200^{\circ} \mathrm{C}$, whereas in halogen bulbs the filament temperature is from 2,200 $-2,500^{\circ} \mathrm{C}$ (tungsten temperature of fusion is about $3,300^{\circ} \mathrm{C}$ ). Since the temperature of fusion of the glass balloon is about 1,000 to $1,300^{\circ} \mathrm{C}$, it is obvious why the contact of the glowing filament and glass particle of the broken glass balloon/cylinder results in the fusion of the glass particle [7]. At this temperature tungsten would oxidise fast and the filament would break, and therefore in case of classic bulbs the filament is located in a glass balloon from which air has been aspirated. The glass balloon is then filled with a mixture of inert gases (usually argon and nitrogen) under low pressure, so that the pressure within the glass balloon in classic bulb is lower than the atmospheric one. On the other hand, the glass cylinder of halogen lamps is filled by vapour of halogen elements (bromine, iodine, etc.) under a pressure higher than the atmospheric one. The cylinder is made of quartz glass which is not sensitive to sudden changes of temperature and can withstand higher operating temperatures (the temperature of halogen bulb glass cylinder can amount up to $\left.500^{\circ} \mathrm{C}\right)$.

Classic tungsten-filament light bulb provides more "yellow" (warm) colour spectrum, whereas in halogen light bulb the filament [8] yields in the visible spectrum more "white" colour. Therefore halogen light bulbs yield light of more intensity compared to the light of the classic filament light bulbs. Halogen light bulbs are used to light the road ahead and for the front fog lights, whereas classic light bulbs are used mainly for signalisation lights on the vehicle (Figure 1).

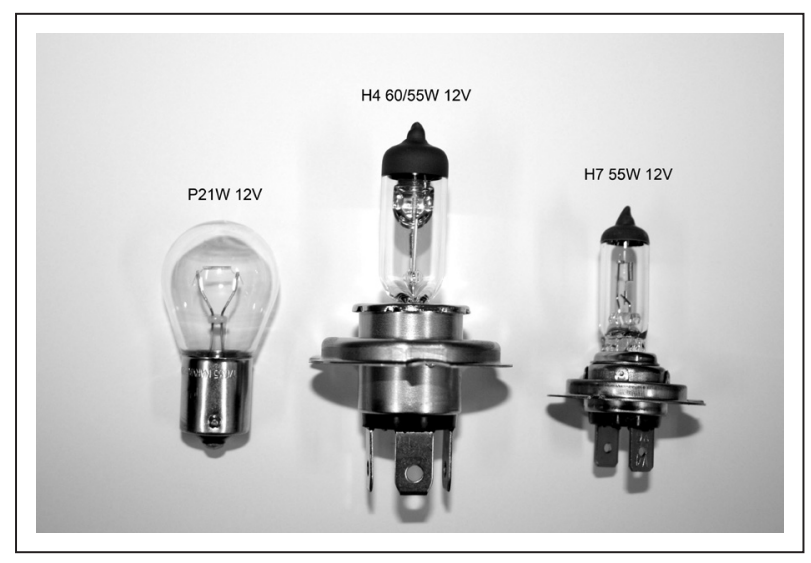

Figure 1 - Standard light bulbs and halogen light bulbs $\mathrm{H} 4$ and $\mathrm{H} 7$ 


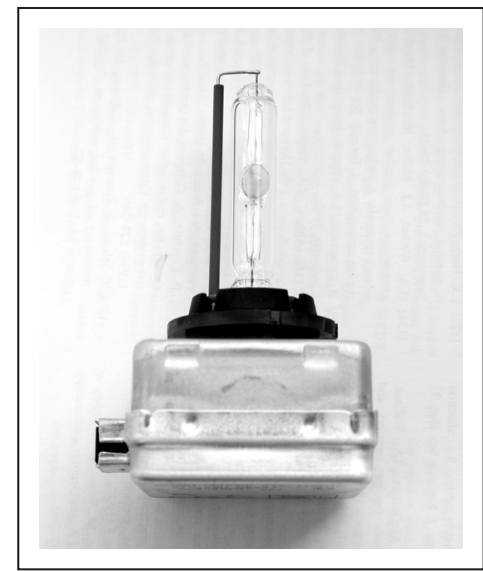

Figure 2 - Light bulbs filled with xenon gas of 35W power

The more recent versions of light bulbs (Figure 2) have no classic filament, and the working principle is based on the emission of the visible light spectrum of ionized noble gas xenon (Xe, 54) which is obtained by fraction distillation of liquid air [9]. Unlike classic light bulbs, xenon light bulbs provide more light at lower consumption of electricity than halogen light bulbs (35W). The colour of the light is similar to daily light and therefore provides better conspicuousness of pedestrians, road and traffic signalisation, and the light bulb lifecycle is much longer [9].

\subsection{Problems during analysis of light bulbs on vehicles damaged in traffic accidents}

Traces on vehicle light bulbs that result as consequence of impact/collision, may be the traces which result from inertia forces (traces of plastic deformation of the filament, or similar) and other traces on light bulbs (change in the appearance of the filament in the form of oxidation, traces of fused and deposited particles of broken glass balloon on the filament, and traces of tungsten oxide on the parts of the light bulb: supports of filaments and the interior of the glass balloon). There are several methods suitable for determining the condition of the filament at the moment of traffic accident, which had been until now mainly based on the analysis of the appearance of the filament observed by an optical microscope. The collision of two vehicles of similar masses and higher collision speeds leaves on the light bulb filament current (reversible) or permanent (irreversible) changes. If the observed filament was cold (light not switched on) at the moment of accident, then these changes occur as current elastic deformation of the filament which after the action of the force returns to its original condition. There are no permanent changes on the filament, and the gap between the coils of the filament helix prior to and following the traffic accident remains the same (Figure 3). In case the light bulb glass balloon (cylinder) breaks, there are no traces of glass particles on the fila- ment itself. In case the filament breaks when it is cold, due to excessive elastic elongation (collision at high speeds) the point at which the filament breaks is located in practice near the filament support $[3,8]$. This place of breakage has sharp edges, and with high magnification, at the cross-section of the point of breaking the border lines of crystal grains are visible.

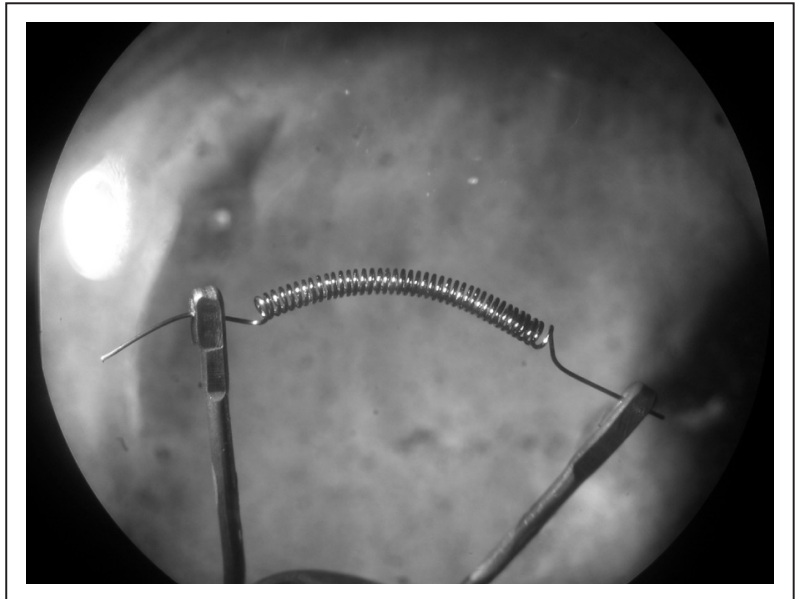

Figure 3 - Light bulb filament without permanent (plastic) deformation of helix

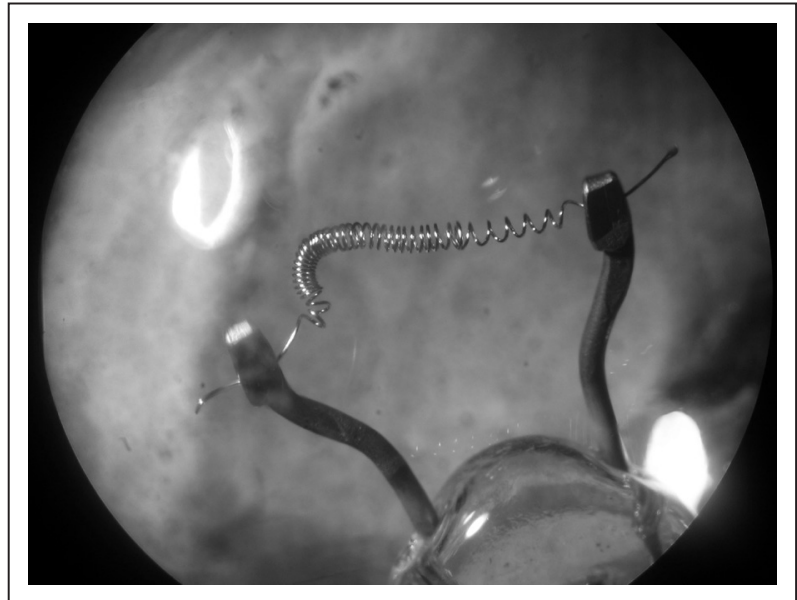

Figure 4 - Light bulb filament with marked permanent (plastic) deformation of helix

If the observed filament at the moment of collision/ impact was the glowing state (the light was on) then the changes occur in the form of current elastic deformation of the filament as well as permanent plastic deformation of the filament which after the force ceases to act, does not return to the original state. On the filament there remain permanent changes in the form and shape of the filament. The spacing between the coils of the filament helix before and after the traffic accident is not the same (Figure 4). The cause of such plastic change in the form of the filament is the exceeded yield point of the filament material, i.e. change in the structure of the crystal grid of the construction material [6]. In case when the light bulb glass balloon (cylinder) breaks there may be residual traces 
of glass particles on the filament itself in the form of fusion or deposit. Regarding different pressures within the glass balloon, which is lower in classic light bulbs than the atmospheric pressure, and in halogen bulbs it is higher than the atmospheric pressure, the expected amount of fused/deposited particles is different. In case of breaking of the filament in glowing state, due to excessive elastic elongation (collision at high speeds) the point of breaking of the filament is approximately around the middle of the filament. This spot of breaking shows traces of fusion. The fusion traces can be in the form of elongation of the breaking edge or in the form of a deposited ball of irregular shape at the point of breaking. This deposited ball at the point of breaking, which is of irregular shape, needs to be distinguished from the deposited ball at the point of breaking, which is of regular shape and indicates a burned-out filament before the traffic accident. In this case it is necessary to compare the traces of existence or non-existence of the filament deformation, and the traces of deposited glass on the filament if the light bulb glass balloon has been broken in the traffic accident.

The problem that occurs in investigation of the light bulb filaments is in case of very low collision/ impact speeds of vehicles of similar masses, and in collision of vehicles of very different masses, even regardless of the collision/impact speed (e.g. collision between a cyclist/motorcyclist and a heavy vehicle of a large mass, etc.). This problem becomes even more pronounced in case of a collision of a high mass vehicle and a pedestrian. In such cases the question is whether the vehicle force impulse in crash/collision is sufficient to cause plastic deformation of the filament or not. When in such a case the glass of the glass balloon/cylinder breaks and causes defragmentation, the only qualitative method of determining the condition of the respective filament at the moment of collision is the analysis of the existence of particles of fused glass on the filament helix. In the past practice, the condition of the light bulb filament was studied by means of an optical microscope. The magnifications used ranged from $4 x$ to $15 x$. When using higher magnifications than these, the problem occurred due to the curvature of the filament, making it impossible for the optical microscope to sharpen only a small segment of the filament, leaving the rest non-sharp, which makes the investigation extremely difficult, especially taking photos of the found state (Figure 5). On the other hand, the mentioned magnification does not allow detailed insight into the appearance of the tiny particles that may be found on the filament (Figure 6). It is difficult to determine whether it is deposited/fused glass or some other particles (fibres, plastics, or similar), and it is obvious that neither the chemical composition of the observed particle can be analysed in this way

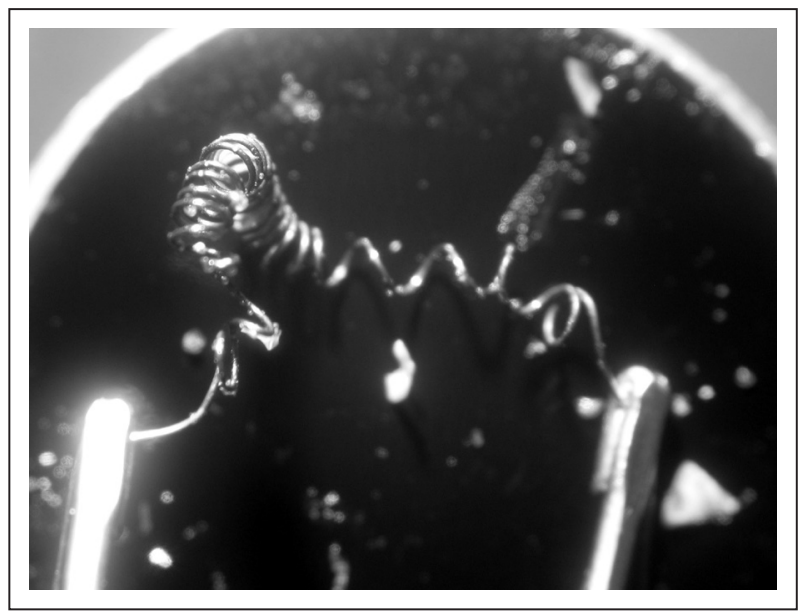

Figure 5 - Traces of glass on the filament of a classic light bulb - photo taken by means of an optical microscope

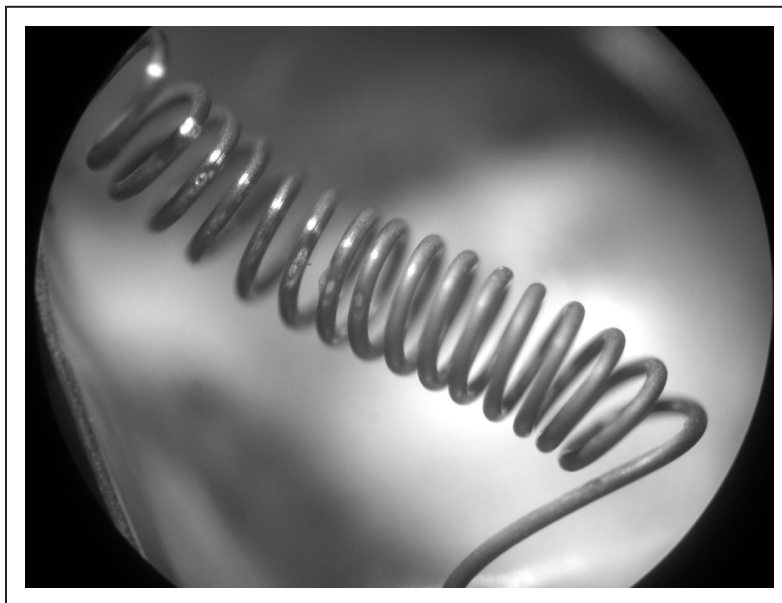

Figure 6 - Traces of glass on a filament of low-beam halogen headlamp (H4) - photo taken by optical microscope

\section{HYPOTHESIS}

The intention of this analysis is to prove that the investigation of the traces of fused and non-fused glass particles of the broken light bulb glass balloon (cylinder) by means of a new technical and technological procedure using SEM/EDX method (Scanning Electron Microscopy/Energy Dispersive X-ray Analysis), i.e. ESEM/EDX electronic microscope (ESEM - Environmental Scanning Electron Microscopy). Such procedure ensures much greater magnification and higher quality of the image in comparison with the optical microscope, allowing also the chemical analysis of glass particles, thus making it possible to determine undoubtedly whether the filament was glowing or not at the moment of the traffic accident, especially in the border cases of the action of inertia forces in collision/ impact. 


\section{EXPERIMENTAL PART}

\subsection{Materials and methods}

In the experimental part the classic light bulbs and the halogen light bulbs $\mathrm{H} 4$ and $\mathrm{H} 7$ were analysed. The environmental scanning electron microscope Philips XL 30 ESEM was used [10, 11, 12]. For the morphology of the glass particles, appearance and study of the filament, the SE, BSE and GSED (Backscattered Electrons and Gaseous Secondary Electron Detector) detectors were used in the range of low and high atmospheric pressure of 0.9 Torr. For the elementary chemical analysis the EDX detector EDAX, and software EDAX Genesis v.6.02 were used [13]. The analysed light bulbs were connected in the electrical circuit by means of a $12 \mathrm{~V}$ direct current source. The light bulbs were under voltage, i.e. the filaments were glowing for about 10 seconds, and after that the light bulb balloons were broken by a simulated impact. On the filament from the broken light bulb glass particles were found, whose chemical composition matched the composition of the broken glass of the light bulb balloon.

\subsection{Research results}

\subsubsection{Classic light bulb}

Analysis of the classic light bulb filament using the scanning electron microscope

A larger number of glass particles was found on the filament, of characteristic spherical form of average size of $25 \mu \mathrm{m}-110 \mu \mathrm{m}$ (Figure 7 ).

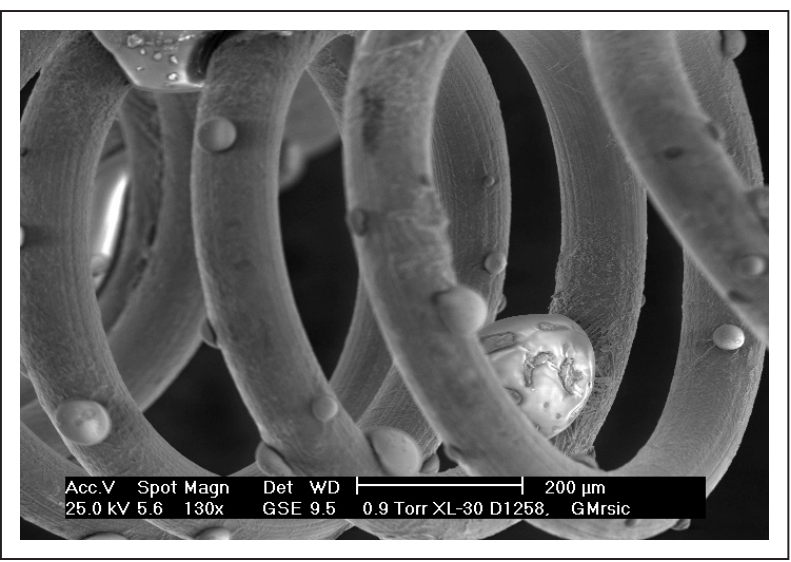

Figure 7 - Deposited and fused glass particles on classic light bulb filament

A larger number of particles is present because the pressure in the light bulb is lower than the atmospheric pressure, and breaking of the glass balloon resulted in adherence of the glass particles to the tungsten filament (Figure 8). Apart from smaller particles, larger glass particles may also be found and they are between the filament helix, easily visible also by the

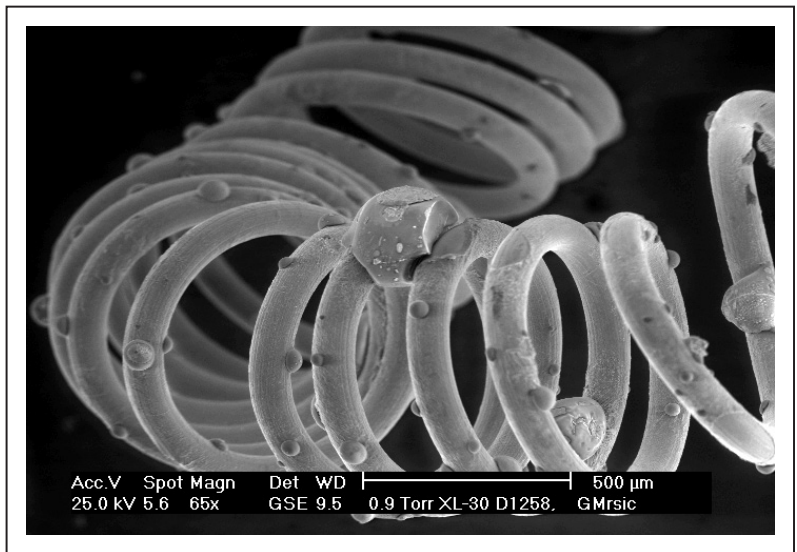

Figure 8 - Greater amount of glass particles on classic light bulb filament due to pressure within light bulb glass balloon which is lower than the atmospheric pressure

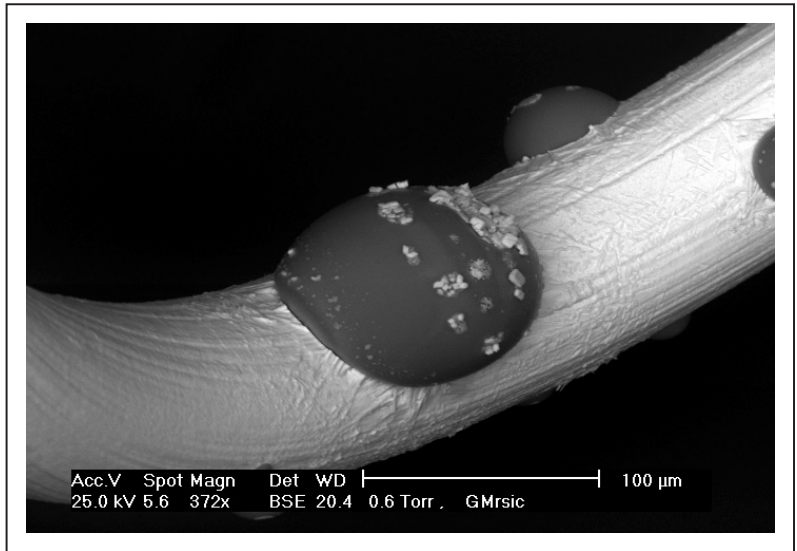

Figure 9 - Deposited glass particles on classic light bulb filament

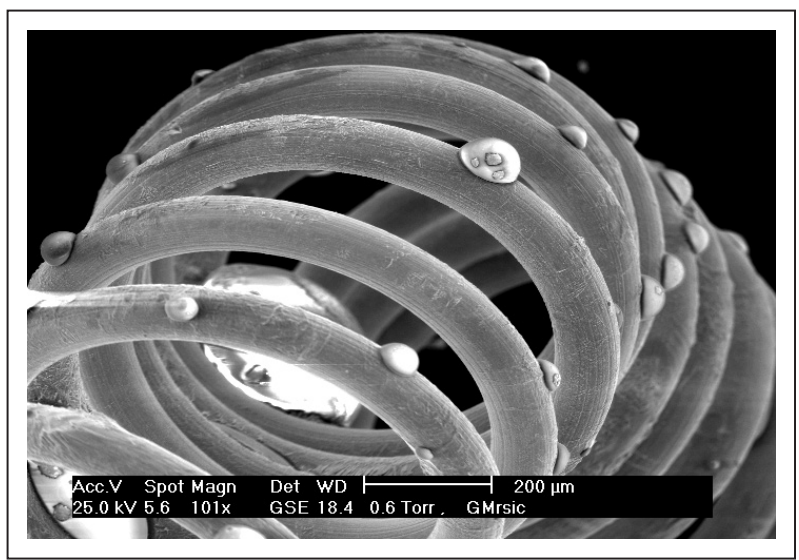

Figure 10 - Deposited glass particles on classic light bulb filament

optical microscope. A part of particles has penetrated the filament (Figures 9 and 10).

Friction, poor handling and by archiving the filament can result in glass particles falling off the filament (Figures 11 and 12).

Such particles are of spherical form due to the cooling of the fused glass on the filament of a certain curvature, and if it is found subsequently, it is even 


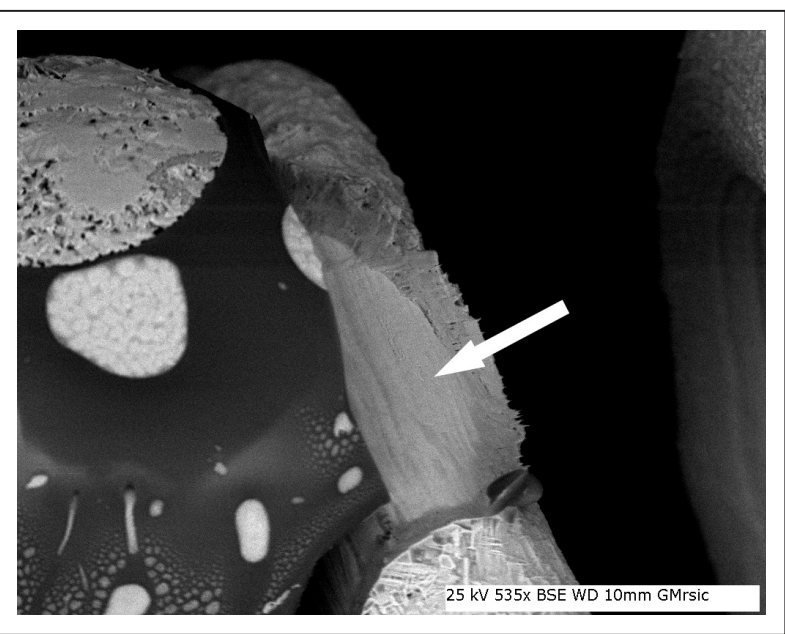

Figure 11 - Field of fallen-off fused glass on the filament

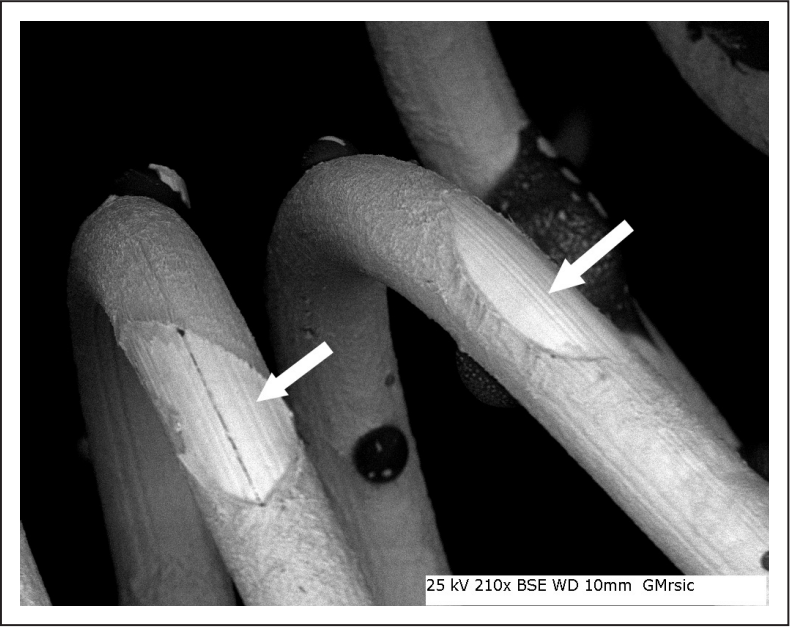

Figure 12 - Field of fallen-off fused glass on the filament

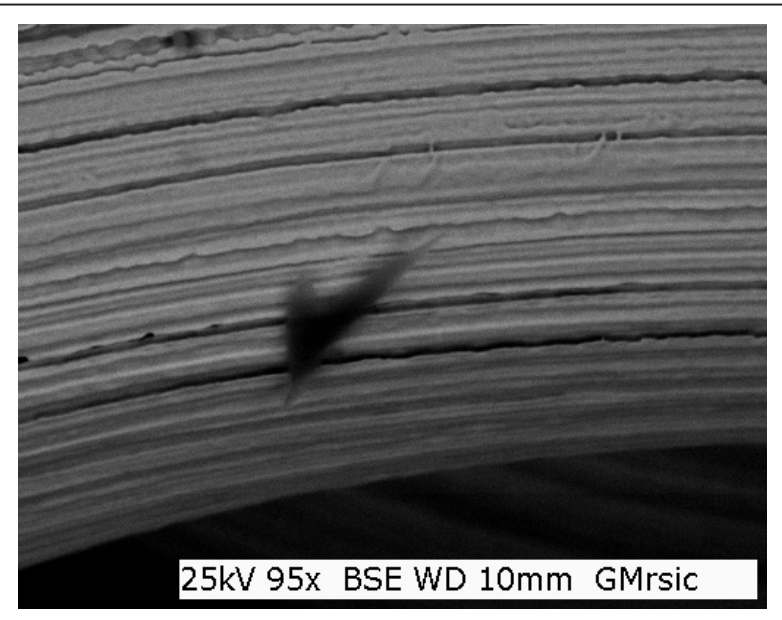

Figure 13 - Fragment of glass found on the filament damaged in cold condition

possible to put it back to the place from which it had fallen off. If the classic light bulb was broken when it was cold, glass fragments can be found on the filament, but without the characteristic round or spherical form. Also, such glass particle did not penetrate into the cold filament as in case of glass particles and the glowing filament (Figure 13).

\subsubsection{Results of chemical analysis of balloon glass, glass particles and filament of a classic light bulb}

The elementary analysis of the filament by means of SEM/EDX method has determined that it is a tungsten filament (100wt\%), and the filament did not change the composition, not even after having been connected it to the electrical circuit. The light bulb balloon glass analysis has shown that due to the non-homogeneity of the glass (Figures 15 and 17) the quantitative analysis of the glass balloon and the glass particles found on the filament cannot be made. In the experiment the qualitative analysis of the balloon glass and the found glass particles on the filament was performed (Tables 1 and 2).

The chemical composition of fused particles of the broken glass balloon on the glowing filament is not sig-

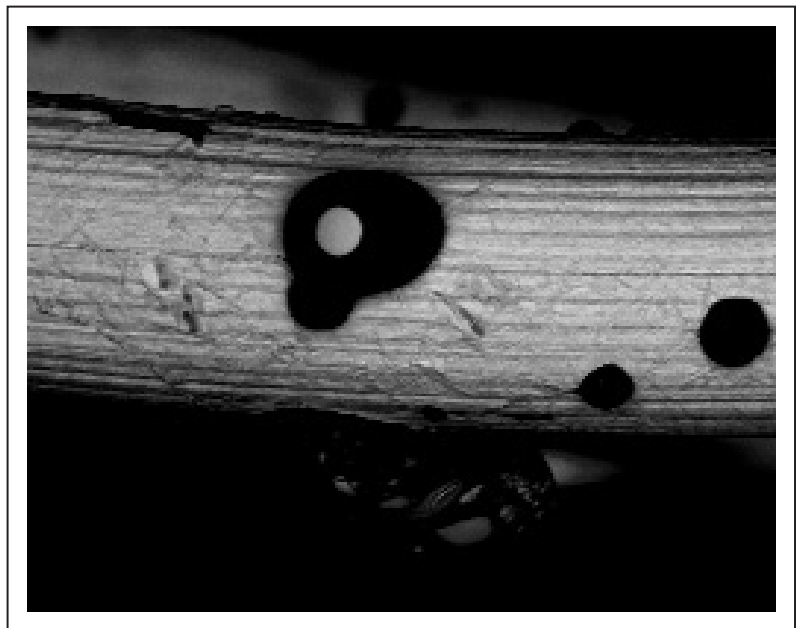

Figure 14 - SEM image

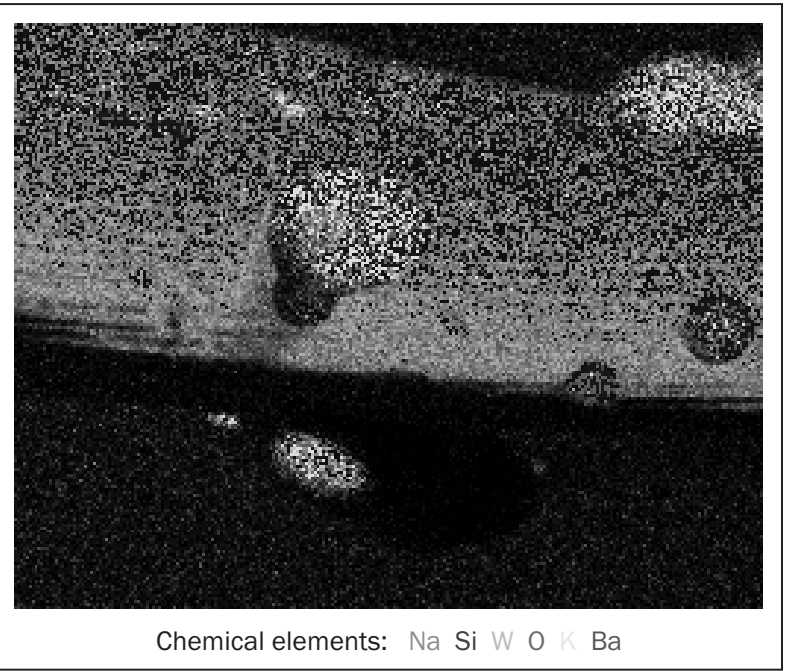

Figure 15 - Distribution of elementary composition of glass particles on the filament 
R. Horvat et al.: Method of Light Bulbs Analysis on Vehicles Damaged in Traffic Accidents

Table 1 - Elementary composition of glass particles on the filament (wt= weight\%)

\begin{tabular}{|c|c|c|c|c|c|c|c|c|c|}
\hline Particles & 0 & $\mathrm{Na}$ & Al & Si & K & $\mathrm{Ca}$ & $\mathrm{Ba}$ & $\begin{array}{l}\text { Particle } \\
\text { size } \\
(\mu \mathrm{m}) \mathrm{x}=\end{array}$ & $\begin{array}{l}\text { Particle } \\
\text { size } \\
(\mu \mathrm{m}) \mathrm{y}=\end{array}$ \\
\hline Particle 1 & 48.10 & 3.25 & 2.44 & 38.56 & 1.78 & 0 & 5.48 & 42.3 & 48.0 \\
\hline Particle 2 & 53.38 & 4.41 & 2.45 & 33.57 & 1.83 & 0 & 4.36 & 36.8 & 33.3 \\
\hline Particle 3 & 45.52 & 4.88 & 2.34 & 33.82 & 3.86 & 1.27 & 8.32 & 32.8 & 30.2 \\
\hline Particle 4 & 54.07 & 2.71 & 2.36 & 35.71 & 1.08 & 0 & 4.08 & 25.7 & 21.7 \\
\hline Particle 5 & 46.33 & 3.85 & 2.27 & 36.50 & 3.29 & 0 & 7.76 & 27.2 & 28.7 \\
\hline $\bar{x}$ & 49.48 & 3.82 & 2.37 & 35.63 & 2.37 & 0.25 & 6.00 & 32.96 & 32.38 \\
\hline SD & 3.993 & 0.870 & 0.075 & 2.053 & 1.159 & 0.568 & 1.945 & - & - \\
\hline
\end{tabular}

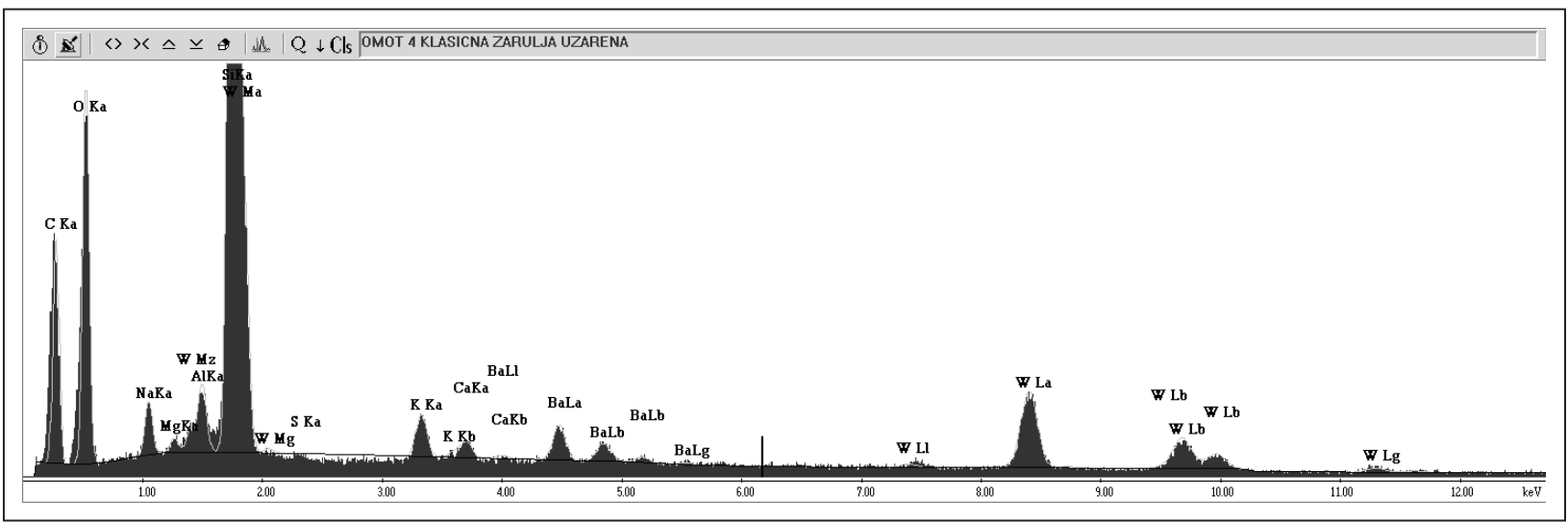

Spectrum 1 - Glass spectrum on the filament

Table 2 - Elementary composition of light bulb balloon glass

\begin{tabular}{||l||c|c|c|c|c|c|c||}
\hline $\begin{array}{r}\text { Chemical } \\
\text { element } \\
\text { (wt\%) }\end{array}$ & $\mathrm{O}$ & $\mathrm{Na}$ & $\mathrm{Al}$ & $\mathrm{Si}$ & $\mathrm{K}$ & $\mathrm{Ca}$ & $\mathrm{BaL}$ \\
\hline Particles & 38.03 & 4.96 & 2.44 & 34.80 & 5.59 & 2.03 & 12.16 \\
\hline Scan 1 & 44.64 & 5.78 & 2.44 & 33.64 & 4.12 & 1.37 & 8.02 \\
\hline Scan 2 & 44.47 & 5.68 & 2.49 & 33.59 & 4.28 & 1.40 & 8.08 \\
\hline Scan 3 & 42.38 & 5.47 & 2.46 & 34.01 & 4.66 & 1.6 & 9.42 \\
\hline $\bar{x}$ & 3.768 & 0.447 & 0.029 & 0.685 & 0.806 & 0.373 & 2.373 \\
\hline SD
\end{tabular}

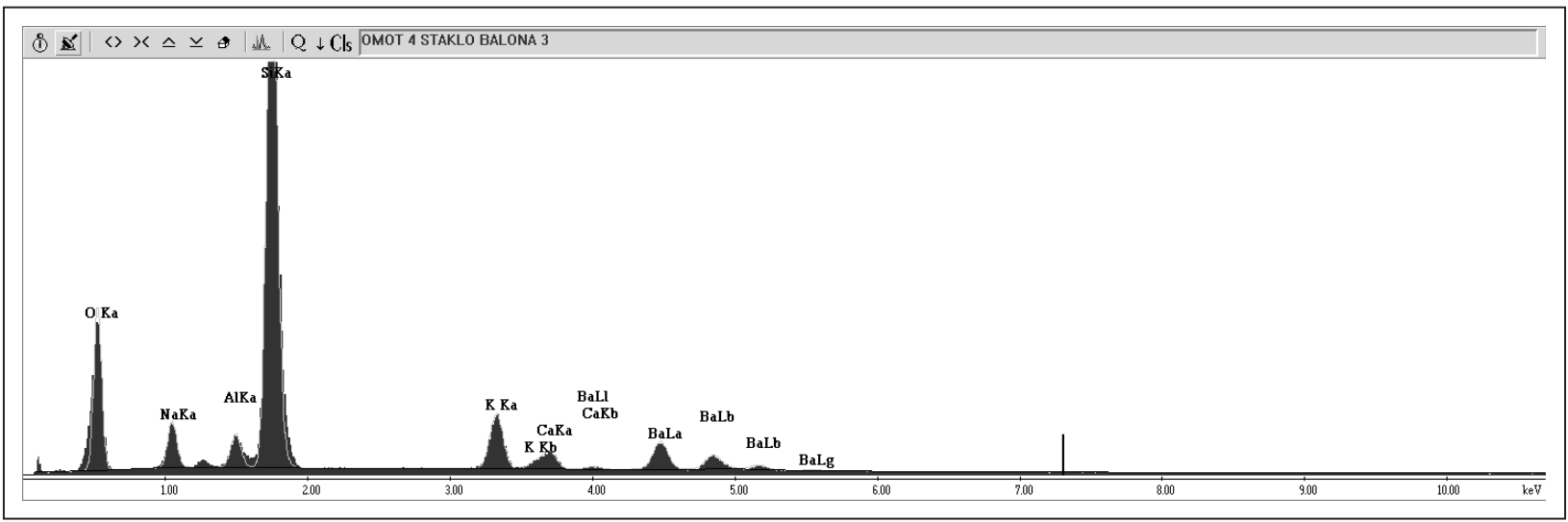

Spectrum 2 - Glass spectrum of light bulb balloon glass 
nificantly different from the chemical composition of the light bulb glass balloon (Figures 14 to 17).

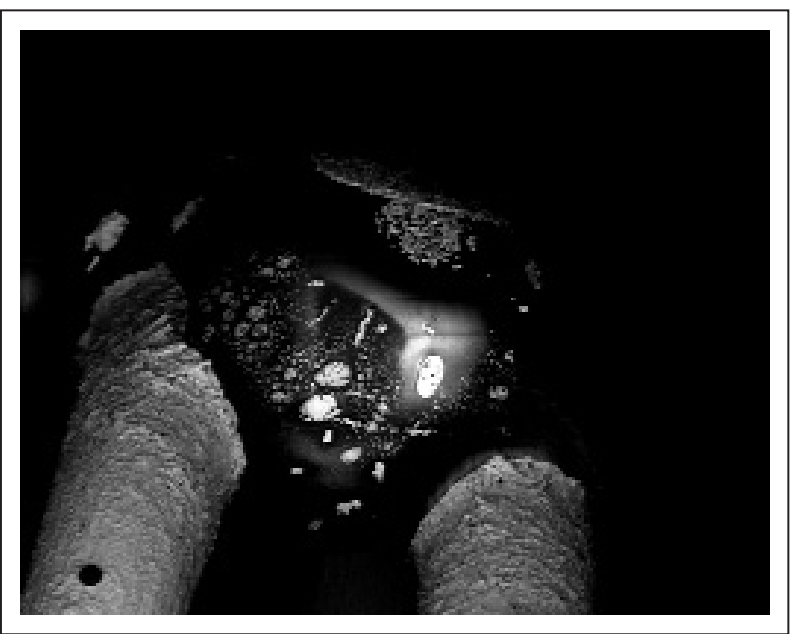

Figure 16 - SEM image

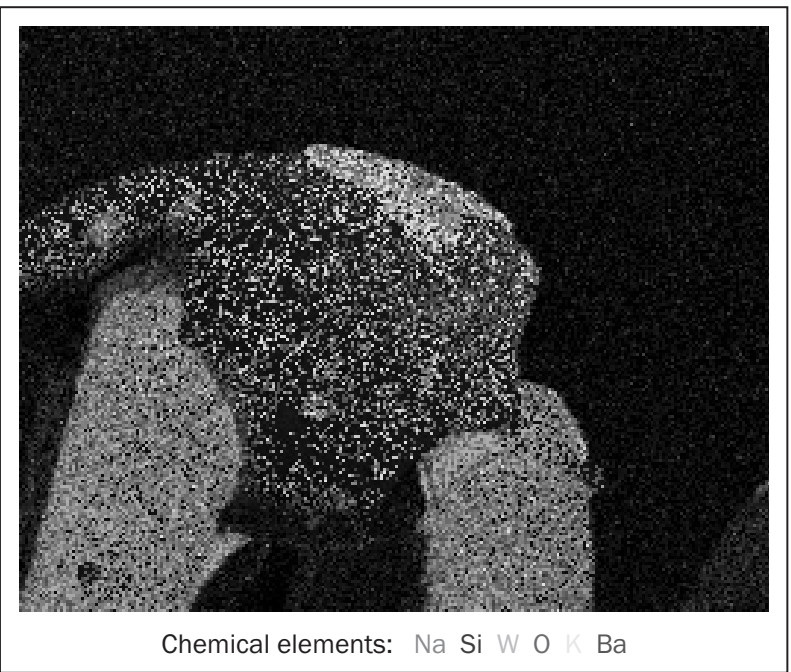

Figure 17 - Distribution of elementary composition of glass particles on the filament

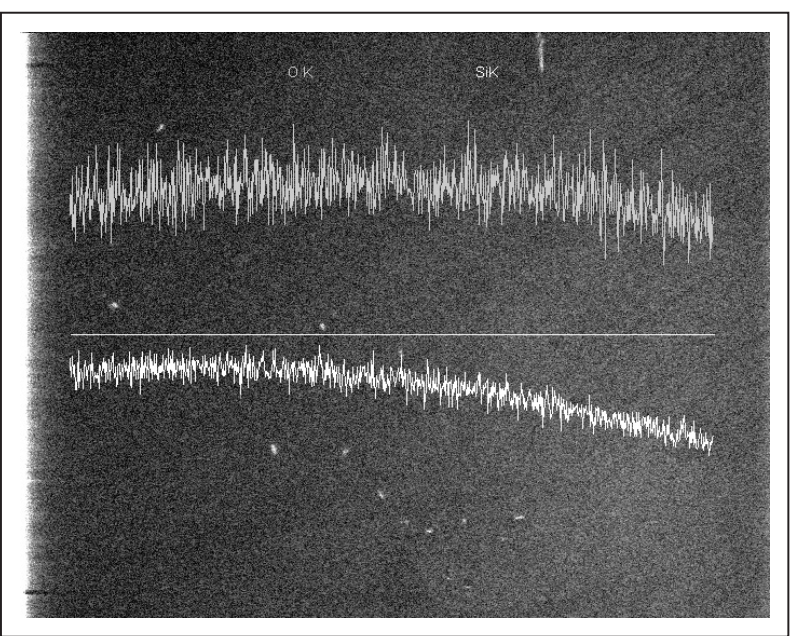

Figure 18 - Distribution of elementary composition of bulb cylinder glass and its (non)homogeneity

\subsubsection{H4 light bulb}

H4 headlamp bulb is a bilux headlamp bulb, i.e. a bulb with two filaments; one low-beam headlamp filament and one high-beam headlamp filament. The pressure within the bulb glass cylinder is higher than the atmospheric pressure. By analysing the cylinder glass of $\mathrm{H} 4$ halogen headlamp bulb, it can be found that due to the non-homogeneity of the glass one cannot determine the exact percentage of silicon-dioxide (SiO2) in glass, which makes it impossible to perform a quantitative analysis of glass and the glass particles found on the filaments (Figure 18). Therefore, during the analysis a qualitative analysis of the cylinder glass and the found glass particles on the filaments was carried out (Tables 3, 4, 5).

\section{Low-beam headlamps}

As in case of classic light bulb, the $\mathrm{H} 4$ light bulb is also connected to the $12 \mathrm{~V}$ direct current source, by only the low-beam headlamp being connected. After having been switched on for about 10 seconds, the light bulb was mechanically broken and the low-beam filament was taken to the support of the electronic mi-

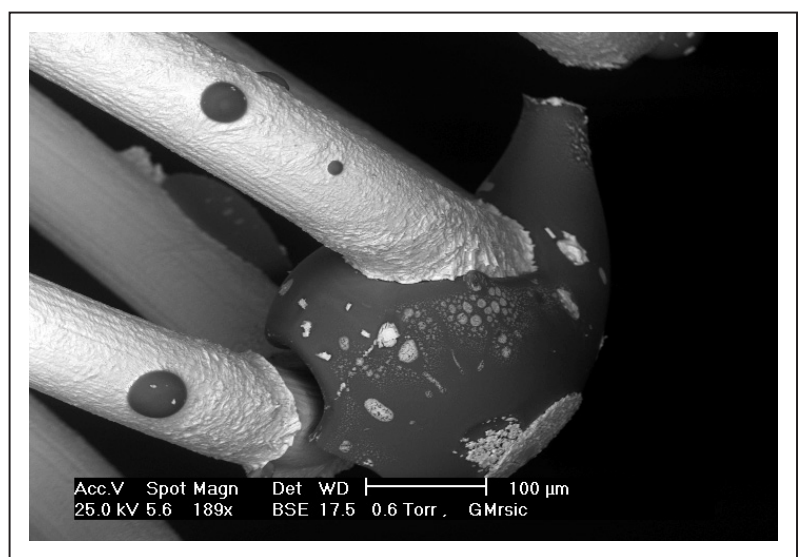

Figure 19 - Glass particle penetrated into filament of the low-beam headlamp $\mathrm{H} 4$

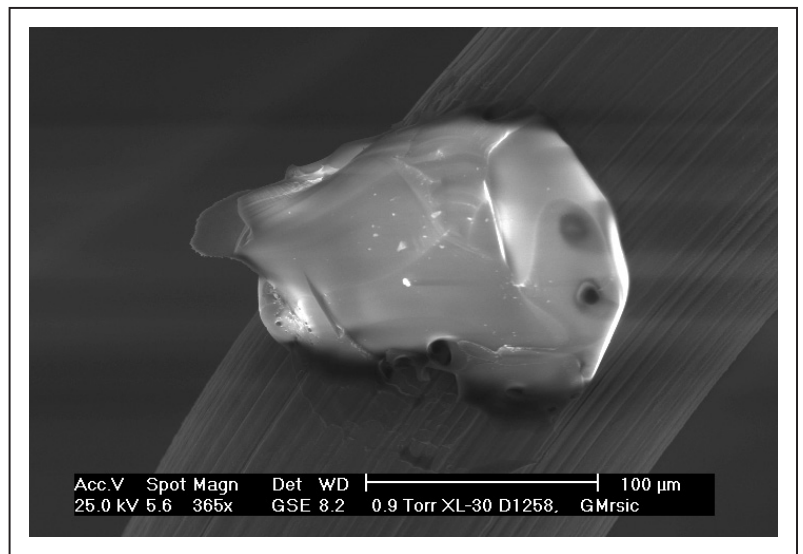

Figure 20 - Fused glass particles on low-beam headlamp $\mathrm{H} 4$ 


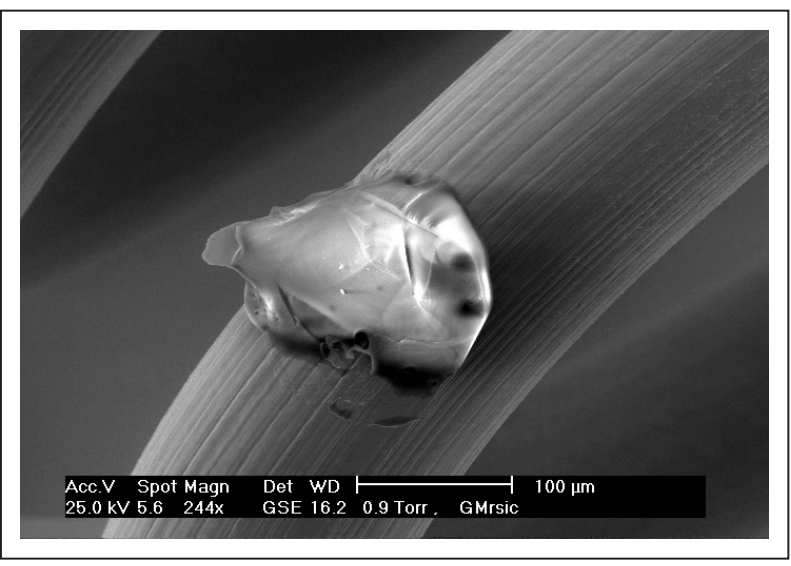

Figure 21 - Deposited glass particle on low-beam headlamp $\mathrm{H} 4$

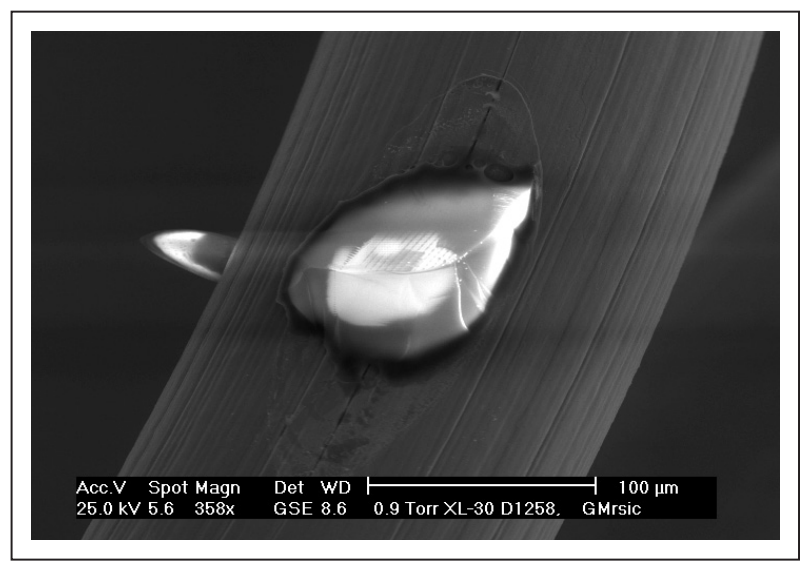

Figure 22 - Deposited glass particles found on the filament of low-beam headlamp H4

Table 3 - Relation of Si and O in glass particles on H4 light bulb filament and their size

\begin{tabular}{|c|c|c|c|c|}
\hline Particles & 0 & Si & $\begin{array}{l}\text { Particle size } \\
\qquad(\mu \mathrm{m}) \mathrm{x}=\end{array}$ & $\begin{array}{c}\text { Particle size } \\
\qquad(\mu \mathrm{m}) \mathrm{y}=\end{array}$ \\
\hline Particle 1 & 50.32 & 49.68 & $130.0 \mu \mathrm{m}$ & $92.3 \mu \mathrm{m}$ \\
\hline Particle 2 & 52.68 & 47.32 & $187.0 \mu \mathrm{m}$ & $162.0 \mu \mathrm{m}$ \\
\hline Particle 3 & 45.92 & 54.08 & $40.2 \mu \mathrm{m}$ & $118.0 \mu \mathrm{m}$ \\
\hline Particle 4 & 50.50 & 49.50 & $49.0 \mu \mathrm{m}$ & $47.7 \mu \mathrm{m}$ \\
\hline Particle 5 & 49.64 & 50.36 & $147.6 \mu \mathrm{m}$ & $21.5 \mu \mathrm{m}$ \\
\hline $\bar{x}$ & 49.812 & 50.188 & - & - \\
\hline SD & 2.456 & 2.456 & - & - \\
\hline
\end{tabular}

croscope. On the filament there were fewer particles of the fused glass than on the classic light bulb filament. It was found that the reason for this was in the pressure within the light bulb glass cylinder which is higher than the atmospheric pressure and at the moment of glass breaking a larger number of broken particles are thrown from the centre of the light bulb outwards (Figures 19 to 22).

Table 3 shows the chemical relations of silicone (Si) and oxygen ( 0 ) in glass particles on the $\mathrm{H} 4$ light bulb filament as well as their size. The glass particles, namely, of $\mathrm{H} 4$ light bulb basically consist of silicone (Si) and oxygen (O).

By comparing the average size of particles determined on the filament of the classic light bulb and $\mathrm{H} 4$ halogen light bulb, a significant difference has been observed. The size of particles (in both cases five measurements were performed) in classic light bulb amounts to $32.96 \mu \mathrm{m} \times 32.38 \mu \mathrm{m}$ whereas in halogen light bulb it is $110.8 \mu \mathrm{m} \times 88.3 \mu \mathrm{m}$. The reason lies in the construction difference in the form of different pressures within the glass balloon and the differences of glass itself of which the glass balloon (classic light bulb), i.e. glass cylinder (halogen light bulb) has been made.

\section{High-beam headlamps}

From the same experiment, the high-beam headlamp filament has been taken, and after having done the analysis the glass particle existence has not been confirmed (Figure 23), but rather the presence of impurities has been determined (Figure 24). The impurities are the consequence of handling the unprotected filament after the glass cylinder had been broken.

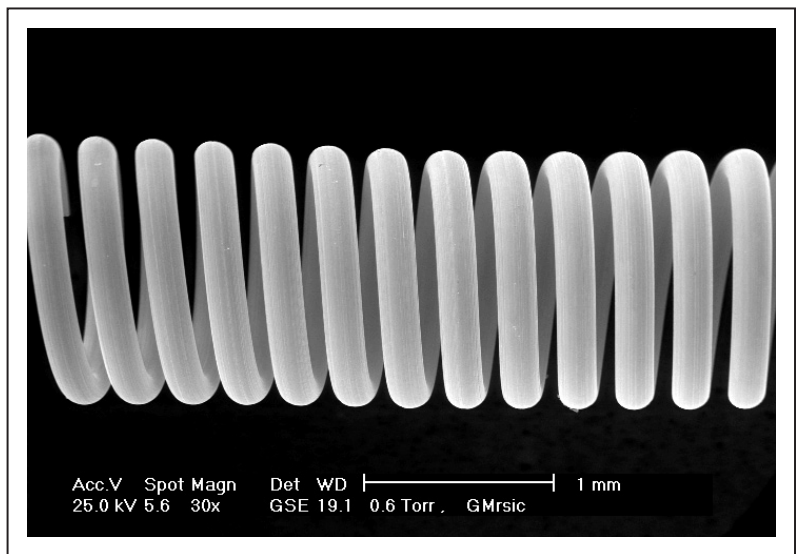

Figure 23 - Filament of high-beam headlamps without traces of glass particles 
Table 4 - Relation of glass particle size on filaments of low- and high-beam headlamps

\begin{tabular}{|c|c|c|c|c|}
\hline Particles $\begin{array}{r}\left.\begin{array}{r}\text { Chemical } \\
\text { element } \\
(w t \%)\end{array}\right) \\
\end{array}$ & 0 & $\mathrm{Si}$ & $\begin{array}{l}\text { Particle size } \\
\qquad(\mu \mathrm{m}) \mathrm{x}=\end{array}$ & $\begin{array}{c}\text { Particle size } \\
\qquad(\mu \mathrm{m}) \mathrm{y}=\end{array}$ \\
\hline Particle 1 (low-beam headlamps) & 59.52 & 40.48 & 23.1 & 29.8 \\
\hline Particle 2 (low-beam headlamps) & 46.28 & 53.72 & 28.8 & 22.6 \\
\hline Particle 3 (low-beam headlamps) & 58.24 & 41.76 & 31.8 & 24.3 \\
\hline Particle 4 (high-beam headlamps) & 54.53 & 45.47 & 64.7 & 53.8 \\
\hline Particle 5 (high-beam headlamps) & 59.49 & 40.51 & 17.4 & 20.1 \\
\hline Particle 6 (high-beam headlamps) & 52.50 & 47.50 & 9.54 & 19.0 \\
\hline $\bar{x}$ & 55.09 & 44.91 & 29.22 & 28.26 \\
\hline SD & 5.168 & 5.168 & - & - \\
\hline
\end{tabular}

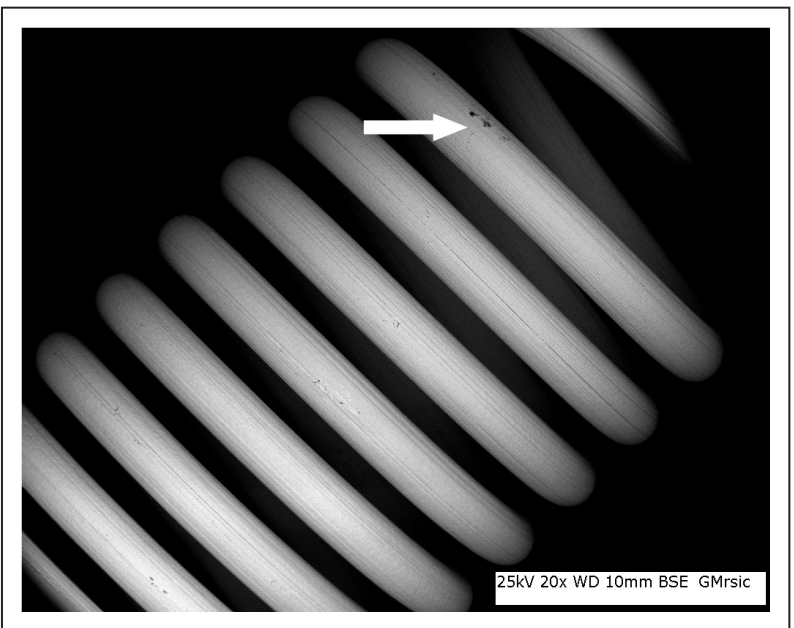

Figure 24 - Filament with traces of impurities of organic composition

\subsubsection{H4 light bulb: both filaments glowing}

$\mathrm{H} 4$ light bulb is connected to the electrical circuit of $12 \mathrm{~V}$ direct current source, with both filaments connected at the same time. After 10 seconds the bulb glass was broken. The filaments were separately taken on

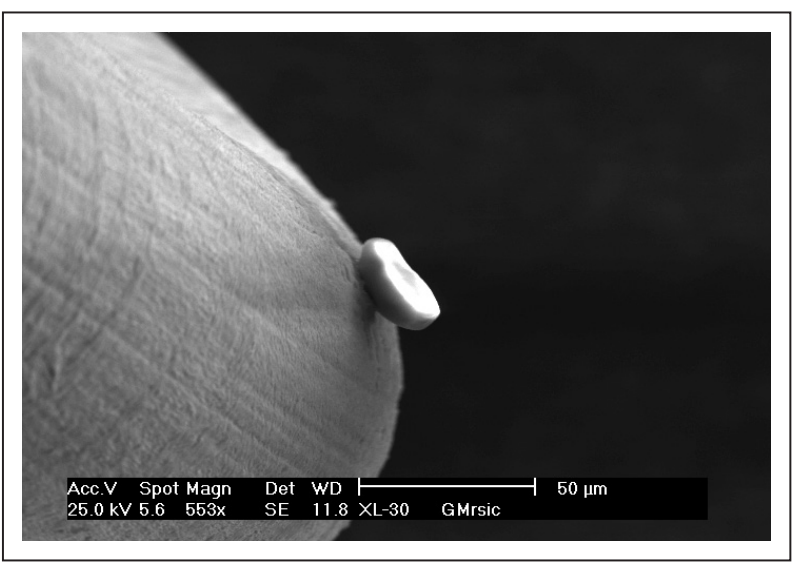

Figure 25 - Filament of low-beam headlamps with traces of glass particles the sample supports of the electronic microscope, and the glass of the same light bulb has been taken in the same way. Elementary analysis has shown that there is no major difference between the balloon glass of this light bulb and the $\mathrm{H} 4$ light bulb where only low-beam headlamps were switched on. Therefore, the data on the composition of the cylinder glass of the broken light bulb in this research will not be specially indicated.

The carried out analysis has confirmed the expected presence of the deposited/fused glass particles on the low-beam headlamp filament (Figure 25) as well as on the high-beam headlamp filament (Figure 26).

Table 5 - Ratio of silicon (Si) and oxygen

(O) in glass balloon of $\mathrm{H} 4$ light bulb

\begin{tabular}{||l||c|c||}
\hline $\begin{array}{r}\text { Chemical } \\
\text { element } \\
\text { (wt\%) }\end{array}$ & 0 & Si \\
\hline Particles & 50.38 & 49.62 \\
\hline Scan 1 & 48.31 & 51.69 \\
\hline Scan 2 & 52.96 & 47.04 \\
\hline $\bar{x}$ & 50.55 & 49.45 \\
\hline SD & 2.329 & 2.329 \\
\hline
\end{tabular}

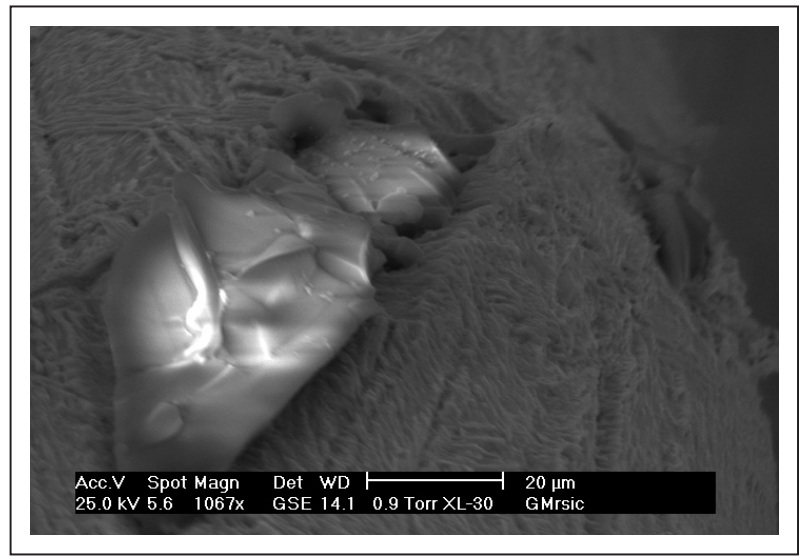

Figure 26 - Filament of high-beam headlamps with traces of impurities of organic composition 
Table 6 - Sizes of glass particles on H7 light bulb filament

\begin{tabular}{|c|c|c|c|c|}
\hline Particles & 0 & $\mathrm{Si}$ & $\begin{array}{c}\text { Particle size } \\
\qquad(\mu \mathrm{m}) \mathrm{x}=\end{array}$ & $\begin{array}{c}\text { Particle size } \\
\qquad(\mu \mathrm{m}) \mathrm{y}=\end{array}$ \\
\hline Particle 1 & 56.76 & 43.24 & 48.0 & 53.0 \\
\hline Particle 2 & 53.63 & 46.37 & 45.9 & 51.7 \\
\hline Particle 3 & 50.70 & 49.30 & 32.8 & 22.0 \\
\hline Particle 4 & 57.96 & 42.04 & 52.9 & 56.7 \\
\hline Particle 5 & 53.01 & 46.99 & 21.8 & 24.4 \\
\hline Particle 6 & 52.17 & 47.83 & 51.8 & 34.6 \\
\hline $\bar{x}$ & 54.038 & 45.962 & 42.2 & 40.4 \\
\hline SD & 2.78 & 2.78 & - & - \\
\hline
\end{tabular}

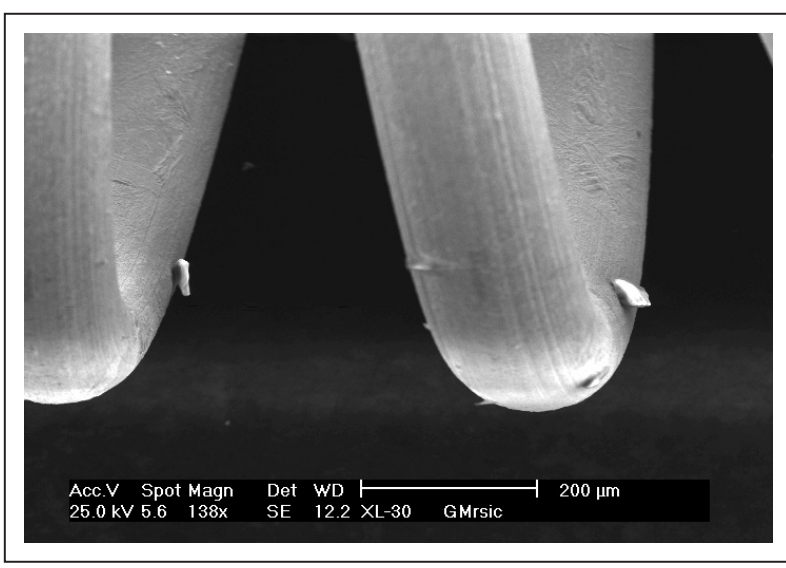

Figure 27 - $H 7$ light bulb filament with traces of glass particles

\subsubsection{H7 light bulb broken in filament in glowing state}

Like $\mathrm{H} 4$ light bulb, the $\mathrm{H} 7$ light bulb is also connected to the electrical circuit of $12 \mathrm{~V}$ direct voltage, for about 10 seconds, and its filament is glowing. After 10 seconds the light bulb glass is mechanically broken and the light bulb filament taken on the support of the electronic microscope.

The analysis has shown the presence of very small particles which are difficult to observe with an optical microscope (Figures 27 and 28). Other essential differences in relation to $\mathrm{H} 4$ light bulb filaments are not noticed (Table 6).

\subsubsection{Bulb H7 with burnt-out filament}

The next analysis was performed on the light bulb of type $\mathrm{H} 7$ on which the filament had burned out before the mechanical damaging. The light bulb was connected to the electrical circuit of the $12 \mathrm{~V}$ direct voltage for about 10 seconds, and after that it was broken mechanically. By taking the filament and after having carried out the analysis, at the place of light

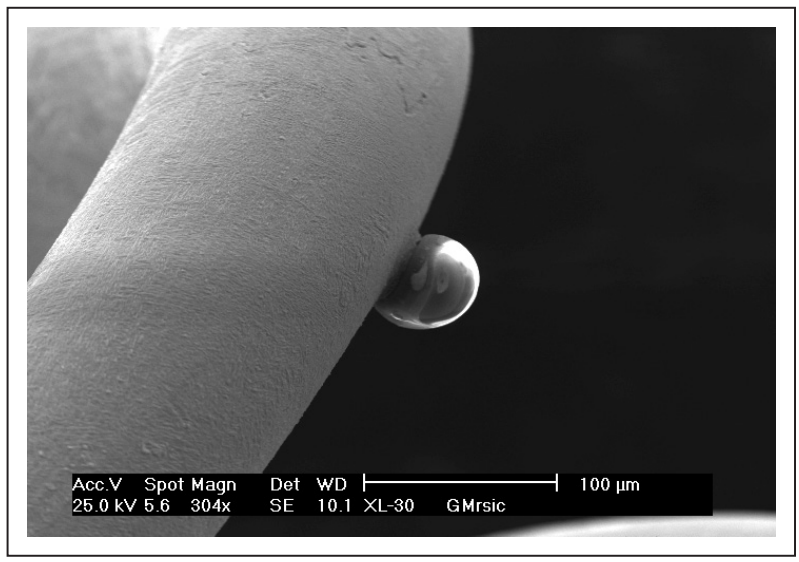

Figure 28 - $\mathrm{H} 7$ light bulb filament with traces of glass particles

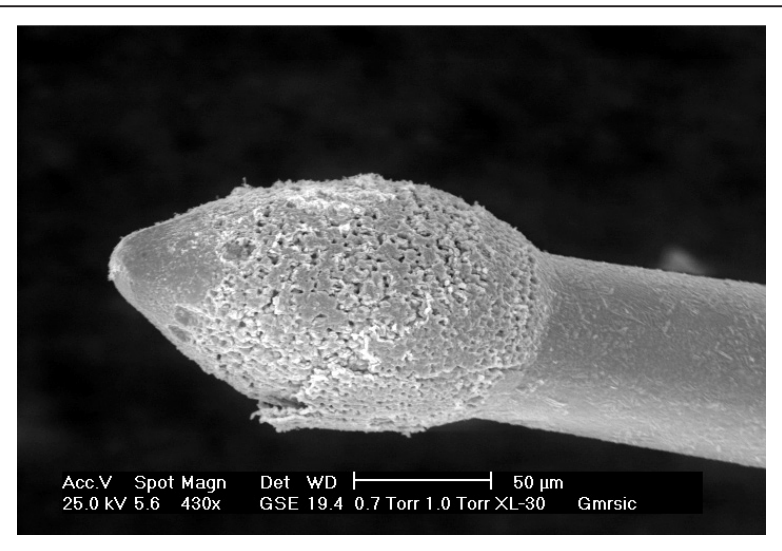

Figure 29 - Filament tip

bulb burning a tip in the form of a fused ball can be seen (Figure 29).

On the filament no traces of the fused glass as result of the broken light bulb glass balloon were found. At the same time no traces of fused glass particles have been found on the connection of the filament and the filament support in the light bulb socket (Figures 30 and 31). 


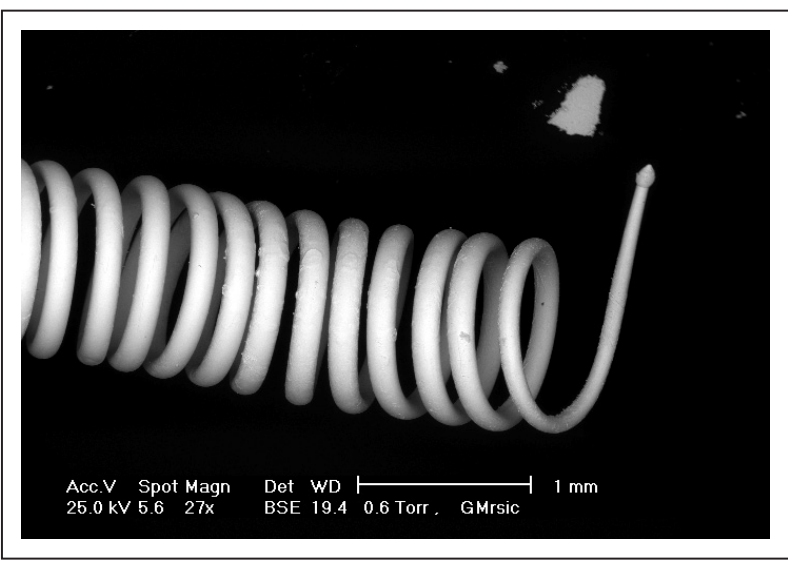

Figure 30 - Filament tip

\section{CONCLUSION}

The scientific research has proven that the new technical and technological method of inspection and analysis of glass traces on the filament using ESEM/ EDX electronic microscope provides accurate and valid result regarding the detection of glass particles on the filament at the moment of the action of inertia forces in the traffic accident.

In comparison with the previous similar research, this original and unique method of analysing automotive light bulbs proves that it is possible to differentiate without doubt various traces of glass on the filament from other traces of organic or inorganic origin. This procedure eliminates any doubt about the possible origin of other traces that are not in relation to the light bulb damaging. It is important to emphasise that by using the scanning ESEM/EDX electron microscope, chemical analysis of the glass can be carried out. Such analysis can be compared to the analysis of the light bulb balloon/cylinder glass in order to detect the origin of the filament in case of bilux light bulbs based on which it can be proven without doubt whether the light bulb was switched on or not at the moment of the traffic accident. Due to the quality of the microscope image, even in case when due to careless handling or other reasons the deposited glass has fallen off the filament, it is possible to identify the places at which the deposited glass had been. Also, it has been proven that this method is more reliable than the method of investigating the filament by means of an optical microscope. This is confirmed by the fact that due to much higher magnification with adequate image quality, the deformation of the image is avoided due to the curvature of the filament, which is the case in using the optical microscope. Apart from the quantity and size of the fused/deposited glass particles on the filament, which depends on the type of light bulb and in case the filament falls out of the light bulb, in this way it is possible to detect the origin of the filament, i.e. the type of the respective light bulb.

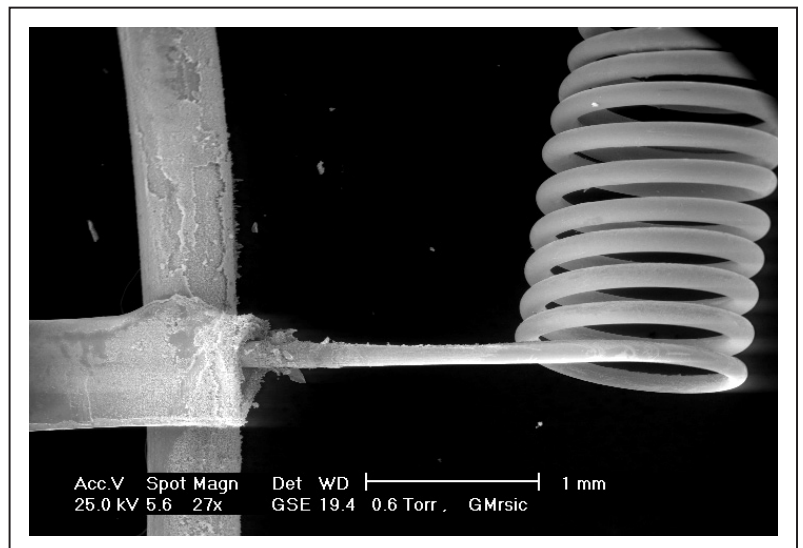

Figure 31 - Filament and connection to filament support

The special characteristic of the carried out scientific analysis lies in the fact that the obtained results can doubtlessly prove the responsibility of the participant for causing or for the occurrence of the traffic accident in case when such a fact is required in the court procedure. At the same time, regarding the original and unique approach to applying the method of analysing automotive light bulbs, the authors will carry out a research of light bulbs filled with the gas xenon (Xe) and of the light bulbs with LED technology.

\section{Mr. SC. RAJKO HORVAT}

E-mail: rajko.horvat@fpz.hr

Sveučilište u Zagrebu

Fakultet prometnih znanosti

Vukelićeva 4, 1000 Zagreb, Republika Hrvatska

BERISLAV BARIŠIĆ-JAMAN, dipl. inž.

E-mail: bbarisic@mup.hr

GORDAN MRŠIĆ, dipl. inž.

E-mail: gmrsic@mup.hr

IGOR ŠPOLJARIĆ

E-mail: ispoljaric@mup.hr

ANDRO VRDOLJAK, dipl. inž.

E-mail: avrdoljak@mup.hr

Forensic Science Centre "Ivan Vučetić", General Police

Directorate, Ministry of Interior

Zagreb, Croatia

IVAN PEHAR

E-mail: ivan.pehar@dekra.hr

Dekra expert d.o.o.

Zagrebačka 118, 1000 Zagreb, Sesvete.

\section{SAŽETAK}

\section{METODA ANALIZE ŽARULJA NA VOZILIMA OŠTEĆENIM U PROMETNIM NESREĆAMA}

Jedna od mjera za povećanje sigurnosti cestovnog prometa u Hrvatskoj uvođenje je obavezne upotrebe dnevnih svjetala na automobilima u prometu na cestama za vrijeme vožnje, bez obzira na vidljivost i doba dana. U članku je opisan novi izvorni tehničko-tehnološki postupak analize automobilskih žarulja u cilju pronalaženja tragova particle stakla razbijenog staklenog balona u graničnim slučajevima djelovanja malih inercijskih sila nastalih uslijed prometne 
nesreće. Vještačenja žarulja u prometnim nesrećama vrlo su rijetko obavljana, stoga je predmet ovog vlastitog znanstvenog istraživanja analiza žarna nit žarulje koje koriste automobili za osvjetljavanje ceste i davanje svjetlosnih znakova, odnosno svih svjetlosno-signalnih uređaja na automobilu uz pomoć novog tehničko-tehnološkog postupka upotrebom SEM/EDX metode. Znanstvenim istraživanjem unaprijeđen je postupak vještačenja analize žarulja na automobilima prilikom utvrđivanja da li su u trenutku prometne nesreće bila upaljena propisan svjetla. U postupku utvrđivanja odgovornosti sudionika za izazivanje ili nastanak prometne nesreće takva činjenica ponekad može imati ključno značenje.

\section{KLUČNE RIJEČI}

prometna nesreća, žarulja, tehničko - tehnološki postupak, svijetla u prometu, mikroskop, rastaljene čestice stakla

\section{LITERATURE}

[1] Zakon o sigurnosti prometa na cestama, Ministarstvo unutarnjih poslova, Zagreb, 2008.

[2] Stauffer E.: Interpretation of Automotive Light Bulb Examination Results: An Intriguing Case, J Forensic Sci 2007; 52 (1): 119 - 124.

[3] Lavabre R, Baudoin P.: Examination of light bulb filaments after a car crash: difficulties in interpreting the results, J Forensic Sci 2001;46(1):147-55.
[4] Vodinelić, V., Baričević, J., Cerovac, V., Pavišić, B., Jelačić, O., Bukljaš, Z., Nikolić, Ž.: Saobraćajna kriminalistika, Suvremena administracija, Beograd, 1988.

[5] Elementi sigurnosti cestovnog prometa / Franko Rotim. Sv. 1: Ekspertize prometnih nezgoda. Zagreb, 1989.

[6] Tehnička enciklopedija, Zagreb, Hrvatski leksikografski zavod.

[7] Barešić Gordan: Vještačenje sijalica vozila sa kriminalističko-tehničkog aspekta, stručna radnja, Zagreb, 1977.

[8] Baker J. S., Aycock T. L., Lindquist T.: Lamp examination for on or off in traffic accidents (vol. 1): Northwestern University Traffic Institute; Illinois, USA; 1990.

[9] Bohner M., Fisher R., Gsheidle R., Keil W., Leyer S., Saier W., Schlögl B., Schmidt H., Siegmayer P., Wimmer A., Zwickel H.: Tehnika motornih vozila (originalni naziv: Fachkunde Kraftfahrzeugtechnik) Pučko otvoreno sveučilište, 2005.

[10] Environmental Scanning Electron Microscopy, An Introduction to ESEM, Philips Electron Optics, Eindhoven, The Netherlands, 1996.

[11] Goldstein J. I., Newbury D. E., Echlin P., Joy D. C., Romig A. D. Jr., Lyman C. E., Fiori C., Lifshin E.: Scanning Electron Microscopy and X-Ray Microanalysis: A Text for Biologists, Materials Scientists, and Geologists, Second Edition.

[12] Mršić G., Žugaj S.: Analiza GSR čestica upotrebom elektronskog mikroskopa (SEM/EDX), Policija i sigurnost, 16 (2007), 3-4; 179-200.

[13] GENESIS GSR- User's Manual, Edax Inc. 